\author{
Krzysztof Stępniak \\ Uniwersytet Kardynała Stefana Wyszyńskiego w Warszawie \\ ORCID: 0000-0001-9716-8835
}

\title{
Jeden świat. Reklama społeczna w dobie pandemii
}

\begin{abstract}
Streszczenie
Artykuł jest fragmentem szerszego projektu badauczego, realizowanego przez autora w październiku-grudniu 2020 roku, dotyczącego materiałów reklamowych zastosowanych przez WHO oraz uybrane kraje świata (Polskę, Australię, Kanadę, Nową Zelandię i RPA) w kampaniach społecznych u czasie pandemii wywołanej przez wirus SARS-CoV-2. W tekście zaprezentowano jedno studium przypadku - kampanię zastosowaną w Polsce, poróunując jej przekazy z materiałami reklamowymi WHO. Główna teza została zaczerpnięta z myśli Iwana Krasteva, który tuierdzi, że pandemia uświadomiła uszystkim, że w obliczu globalnego zagrożenia uszyscy ludzie są mieszkańcami „Jednego Świata”. W całym badaniu zastosowano triangulację dwóch metod badawczych - case study oraz interpretacji kompozycyjnej Gillian Rose. Aby zbadać warstwę werbalną komunikatów, posłużono się modelem komunikacji językowej Romana Jakobsona. W warstuie językowej komunikatów założono ich znaczną perswazyjność. W warstuie wizualnej, ze względu na prostotę formy, ograniczono się do modalności kompozycyjnej ze szczególnym uuzględnieniem kolorystyki i znaków ikonicznych. Tekst pokazuje, jak ważną rolę w komunikacji, zułaszcza w czasach pandemii, pełnią społeczne kampanie reklamoue. Paradoksalnie, pandemia stanowiąca zagrożenie dla ludzkości może otworzyć także nowe, komparatystyczne obszary badań dotyczących skuteczności środków komunikacji masowej zastosowanych w jednych krajach, które z powodzeniem będą mogły być wykorzystane w innych.
\end{abstract}

Słowa kluczowe: case study, COVID-19, Polska, reklama społeczna, Światowa Organizacja Zdrowia.

\section{One World. Social advertising in the age of a pandemic}

\begin{abstract}
The article is an excerpt from a wider research project carried out by the author in OctoberDecember 2020, concerning advertising materials used by WHO and selected countries (Poland, Australia, Canada, New Zealand and South Africa) in social campaigns during the SARS-CoV-2 pandemic. This text presents one case study - a campaign used in Poland, comparing its messages with WHO advertising materials. The main thesis was taken from the thought of Ivan Krastev, who claims that the pandemic made everyone realize that all people are inhabitants of "One World" in the face of a global threat. The entire study used the triangulation of two research methods - case study and compositional interpretation by Gillian Rose. Roman Jakobson's model of linguistic communication was used to examine the verbal layer of messages. In the linguistic layer of the messages, their considerable persuasiveness was assumed. In the visual layer, due
\end{abstract}


to the simplicity of the form, it is limited to the compositional modality, with particular emphasis on colors and iconic signs. The text shous how important a role in communication, especially in times of a pandemic, is played by social advertising campaigns. Paradoxically, a pandemic that threatens humanity may also open up new, comparative areas of research on the effectiveness of mass communication means used in some countries, which can be successfully used in others.

Keywords: case study, COVID-19, Poland, social advertising, World Health Organization.

\section{Wprowadzenie}

Rozwój cywilizacji przyniósł pouszechny wzrost poziomu życia, dobrobytu społeczeństw, internet zbliżył pojedynczych ludzi, nowoczesne samoloty zmniejszyły odległości między kontynentami. Pouszechne dążenie do rozwoju przyćmiło jednakże świadomość kosztów przez niego generowanych, przede wszystkim dla środowiska naturalnego Ziemi. I choć od lat uczeni ostrzegali o możliwych katastrofalnych skutkach wywoływanych przez człowieka zmian klimatycznych, procesy degradacji planety pogłębiają się, powodując nowe zagrożenia i kataklizmy. Wybuch pandemii spowodowanej wirusem SARS-CoV-2 boleśnie uświadomił ludzkości wieloletnie zaniedbania, bagatelizowanie ostrzeżeń i brak reakcji na nie.

Wyniki sondaży przeprowadzanych wśród 750 ekspertów i liderów politycznych przed corocznymi Światouymi Forami Ekonomicznymi (World Economic Forum, WEF) w Davos, publikowane w Global Risk Report, już w 2006 roku uskazywały na możliuość uybuchu światowej epidemii. W 16. edycji raportu ${ }^{1}$ przedstawiono pierusze wnioski z przebiegu walki z koronawirusem w skali świata, umieszczając jednocześnie pandemie chorób zakaźnych wśród pięciu najważniejszych ryzyk będących śmiertelnym zagrożeniem dla świata. Pozostałe cztery to ekstremalne zjawiska pogodowe, niepowodzenie działań na rzecz poustrzymania zmian klimatycznych, degradacja przez człowieka środowiska naturalnego oraz zanik bioróżnorodności. Choroby zakaźne uznano także za jedno z tych zagrożeń, które przyniesie ludzkości - w perspektywie 1-2 lat - najgorsze skutki, jeśli rozwiną się w kolejne pandemie.

Autorzy raportu z 2021 roku, analizując charakter, przebieg i skutki działań podejmowanych w walce z pandemią przez podmioty krajowe i międzynarodowe, wskazują między innymi na znaczenie właściwego komunikowania publicznego - zarówno na szczeblach krajowych, jak i międzynarodowym - i przeciwdziałania rozprzestrzeniającej się dezinformacji. Może temu służyć gromadzenie i udostępnianie informacji związanej z COVID-19, reakcja na pandemię wymaga bowiem „globalnej współpracy, wymiany informacji i koordynacji” oraz „poprawy jasności i spójności informacji o ryzyku i zualczania dezinformacji" 2 .

Jednym z narzędzi zwiększającym skuteczność dotarcia z właściwą informacją do opinii publicznej są kampanie społeczne, które jednocześnie nakłaniają do podjęcia

${ }_{1}$ Global Risks Report 2021, 16th ed., Cologny-Geneva 2021.
${ }^{2}$ Ibidem, s. 73, 25. 
właściwych zachowań i zaleceń w związku z rozwijającą się pandemią. Początek tego rodzaju działaniom dała Światowa Organizacja Zdrowia (World Health Organisation, WHO), występując z szeroką akcją informacyjno-propagandową dotyczącą walki $\mathrm{z}$ covidouym zagrożeniem.

\section{Jeden świat według Krastewa}

Źródłem inspiracji do podjęcia badań nad kampaniami reklamouymi dotyczącymi COVID-19, których fragment autor pragnie zaprezentować w tym artykule, stały się słowa Iwana Krastewa, autora książki Nadesz ło jutro. Jak pandemia zmienia Europę. Krastew, uyliczając $u$ niej skutki pandemii koronawirusa dla różnorodnych dziedzin życia społecznego oraz politycznego Europy i świata, pisze między innymi:

Po raz pieruszy chyba ludzie na całym świecie prowadzą te same rozmowy i dzielą ten sam strach. Siedząc $w$ domach, spędzając niezliczone godziny przed ekranami komputerów i telewizorów, ludzie porównują to, co im się przytrafia, z tym, co spotyka innych ludzi gdzie indziej. Być może to tylko jakiś osobliwy moment w naszej historii, ale nie da się zaprzeczyć, że doświadczamy właśnie czegoś, co przypomina życie w Jednym Śuiecie³.

Pandemia COVID-19 - jako unikatowe, od czasów hiszpanki, zjawisko w nowoczesnym świecie - od początku stała się przedmiotem badań w wielu ośrodkach naukowych, nie tylko związanych z medycyną ${ }^{4}$. Uczeni, porażeni skalą zjauiska obnażającego słabość ludzkości u radzeniu sobie z koronawirusem, zadają dramatyczne pytania: "Co jest nie tak z naszym systemem, że katastrofa zaskoczyła nas nieprzygotowanych, mimo że naukowcy ostrzegali nas przed nią od lat?"'. Zmagania z pandemią, jej przebieg i skutki - w wielu dziedzinach i branżach, na których odcisnęła sue piętno - na lata pozostaną u zbiorowej pamięci. Będą też niewątpliwie przedmiotem licznych analiz.

Podążając za myślą Krastewa, można już na przykład zbadać, jakie działania zostały podjęte na początku pandemii przez poszczególne państwa u celu szybkiego zapoznania

\footnotetext{
${ }^{3}$ I. Krastew, Nadesz ło jutro. Jak pandemia zmienia Europe, przeł. M. Sutouski, Wydawnictwo Krytyki Politycznej, Warszawa 2020, s. 86.

${ }_{4}^{4}$ Zob. np. A. Casero-Ripollés, Impact of COVID-19 on the media system. Communicative and democratic consequences of news consumption during the outbreak, „El Profesional de la Información" 2020, Vol. 29, No. 2, s. 1-11, https://core.ac.uk/download/pdf/326769003.pdf, https://doi.org/10.3145/epi.2020.mar.23 (dostęp: 78.02.2021); R.K. Nielsen et al., Navigating the 'Infodemic': How People in Six Countries Access and Rate News and Information about Coronavirus, Oxford 2020, https://reutersinstitute.politics.ox.ac.uk/sites/default/files/2020-04/ Navigating\%20the\%20Coronavirus\%20Infodemic\%20FINAL.pdf (dostęp: 8.02.2021) (Raport z badania przeprowadzonego w Argentynie, Niemczech, Korei Południowej, Hiszpanii, Wielkiej Brytanii i USA. Truają także prace $\mathrm{w}$ ramach międzynarodowego projektu 'Pandemic Emergency in Social Perspective. Evidence from a large Web-survey research' (PESP-8 Project), obejmującego Włochy, Czechy, Francję, Niemcy, Polskę, Hiszpanię, Szwecję, Wielką Brytanię, koordynowane przez Università Cattolica del Sacro Cuore u Mediolanie i L'Università di Milano-Bicocca.

${ }_{5}$ S. Žižek, Pandemia! COVID-19 trzęsie światem, przeł. J. Maksymowicz-Hamann, Wydawnictuo Relacja, Warszawa 2020, s. 13.
} 
obywateli z podstawowymi informacjami na temat COVID-19 i zasadami profilaktyki w obliczu powszechnego zagrożenia, i jak miały się one w stosunku do uniwersalnego przekazu WHO.

Ponieważ materiały kampanii przygotowanych przez WHO w czasie pandemii zostały zaimplementowane przez wiele krajów, w badaniu posłużyły jako wzorzec, punkt odniesienia dla poróunania (jako głównego celu badawczego) z materiałami reklamouymi (plakatami, ulotkami) użytymi w antycovidowych kampaniach kilku wybranych krajów (Polski, Australii, Nowej Zelandii, Kanady i RPA).

Ze względu jednak na konieczność ograniczenia objętości tekstu zostanie w nim przedstawiony jedynie fragment badania zawężony do jednego case study - Polski. Całemu badaniu autor zamierza poświęcić oddzielną, obszerniejszą publikację.

\section{Metodologia badania}

Na etapie projektowania badania, z racji obszerności materiału badawczego, jednym z zasadniczych problemów był dobór metody i próby badauczej. Zastosowano więc metodę case study, która pozuala formułować pewne uogólnienia przy ograniczeniu próby do kilku zaledwie studiów przypadku. Może być ona bowiem „dobrym sposobem na wykazanie cech charakterystycznych danego procesu lub danej instytucji” ${ }^{\prime}$, tym bardziej że, zdaniem Benta Flyvbjerga,

można dokonywać uogólnień na podstawie jednego przypadku, a studium przypadku może być centralne dla naukowego rozwoju dokonującego się poprzez uogólnienie, jako dodatek lub alternatywa dla innych metod. Znaczenie formalnego uogólnienia jako źródła rozwoju naukowego jest jednak przeceniane, podczas gdy «siła przykładu» jest niedoceniana?

Uwzględnienie u badaniu kilku przypadków (multi-site case study) może dostarczyć wniosków o większym poziomie wiarygodności, potwierdzać je bowiem będzie więcej źródeł ${ }^{8}$.

Po ustępnym badaniu uybrano (poza Polską) te państua, które leżą na różnych kontynentach, w różnych szerokościach geograficznych, przynależą do różnych kultur, cechuje je wielokulturowość i wieloetniczność, ich językiem urzędouym (bądź dominującym) jest język angielski. W założeniu autora kraje uybrane w logicznej próbie badawczej są bardzo zróżnicowane, ale uszystkie są członkami WHO. Przedmiotem

\footnotetext{
${ }^{6}$ A. Dańda, J. Lubecka, Casebook. Metodologia tworzenia case study, Wyższa Szkoła Europejska im. ks. Józefa Tischnera, Kraków 2010, s. 4.

${ }^{7}$ B. Flyvbjerg, Pięć mitów o badaniach typu studium przypadku, „Studia Socjologiczne” 2005, nr 2, s. 51.

${ }^{8}$ P. Mielcarek, Metoda case study $w$ rozwoju teorii naukowych, „Organizacja i Kierowanie” 2014, nr 1, s. 114; zob. też J. Audet, G. d'Amboise, The Multi-Site Study: An Innovative Research Methodology, „The Qualitative Report” 2012, Vol. 6, No. 2, s. 1-18, https://doi.org/10.46743/21603715/2001 (dostęp: 30.12.2020); J. Gustafsson, Single case studies vs. multiple case studies: A comparative study, 2017-01-12, https://wuw.diva-portal.org/smash/get/diva2:1064378/ FULLTEXT01.pdf (dostęp: 30.12.2020).
} 
analizy stały się dostępne $\mathrm{u}$ internecie u październiku-grudniu 2020 roku plakaty i ulotki zuiązane z COVID-19, publikowane przez oficjalne organy rządowe (resorty zdrowia) wybranych do badania państu, traktowane w badaniu jako nadawcy komunikatu. Tego typu materiały wizualne dają możliwość szybkiego przekazu treści od nadawcy do odbiorcy, łączenia jego warstuy informacyjnej z perswazyjnymi argumentami (uerbalnymi i wizualnymi) ze sfery racji, ale umożliwiają też suego rodzaju, jak mówi Banks, „ugląd w społeczeństwo”. Wspomnianym już punktem odniesienia (uzorcem) w analizie kampanii antycovidowych w poszczególnych krajach stały się materiały informacyjne (plakaty i ulotki) przygotowane przez WHO.

Przyjmując tezę o jedności świata w obliczu pandemii, za główną tezę autor w całym badaniu postawił kilka pytań badawczych, które pozwolą na jej weryfikację:

- Czy uybrane do badania kraje wzorowały się, przygotourjąc kampanie informacyjne w swoim kraju, na materiałach przygotowanych przez WHO?

- Czy przekazy w antycovidouych kampaniach społecznych, prowadzone w poszczególnych krajach, były do siebie zbliżone, czy się znacznie różniły?

- Czy rzeczywiście globalna pandemia wywołana przez SARS-CoV-2 pokazała, że żyjemy w jednym świecie?

Spośród modeli związanych z reklamą jako aktem komunikacyjnym do zbadania języka reklam społecznych związanych z pandemią, przygotowanych przez WHO oraz władze wybranych państu, zastosowano model komunikacji Romana Jakobsona ${ }^{10}$. Za uyborem metodologii opartej na tym schemacie, przy pełnej świadomości jego niedoskonałości ${ }^{11}$, przemawia linearność przepłyuu informacji od nadaucy do odbiorcy, zakładana w badanych kampaniach, a także wynikająca z tego modelu typologia funkcji języka, dająca możliwość oceny hierarchii w stosowaniu określonych środków językouych u zależności od przyjętych celów komunikacyjnych, czyli ustalenie funkcji dominującej w komunikacie, ujawniającej intencje nadawcy.

Dla przyjętego przez siebie modelu komunikacji - nadawca $\rightarrow$ [kontekst, komunikat, kontakt, kod] $\rightarrow$ odbiorca - Jakobson ustalił sześć podstawowych funkcji języka: ekspresyuną (emotywną), poznawczą (informatyuną), poetycką (estetyczną), fatyczną, metajęzykową i impresywną ${ }^{12}$.

Która zatem z tych funkcji języka występuje w badanych przekazach i która z nich jest dominująca, to podstawowe pytania, które posłużyły do zbudowania następujących hipotez kierunkowych:

H1. Celem antycovidowych kampanii jest przede uszystkim przekazanie odbiorcy informacji o zagrożeniach niesionych przez pandemię. Dlatego w warstuie werbalnej przekazów ważna będzie funkcja informatyuna.

\footnotetext{
${ }_{9}^{9}$ M. Banks, Materiały wizualne w badaniach jakościowych, przeł. P. Tomanek, Wydawnictwo Naukowe PWN, Warszawa 2013, s. 23.

${ }^{10}$ R. Jakobson, Poetyka w świetle językoznawstwa, „Pamiętnik Literacki” 1960, nr 2, s. 431-473.

11 J. Lalewicz, Krytyka teorii funkcji mowy Bühlera-Jakobsona, „Teksty” 1973, nr 6, s. 16-33; A. Ryłko-Kurpiewska, Kontrowersje wokół tradycji badań nad komunikatem reklamowym, „Studia Medioznawcze” 2007, nr 4, s. 51-73.

12 R. Jakobson, Poetyka..., s. 434-440.
} 
H2. Oprócz informacji przekazywanej w kampaniach reklamouych nadrzędnym celem jest skłonienie odbiorcy do określonych działań, postaw i zachowań, które chronić go będą przez zakażeniem. Dominującą zatem funkcją języka przekazów będzie funkcja impresywna.

H3. Ważna w badaniu wydaje się także kategoria nadawcy. W kampaniach społecznych, nastawionych na zmianę postaw, przyjęcie przez jednostkę/społeczeństwo określonych zachowań (lub zaniechanie innych), nadawca, aby osiągnąć określony poziom internalizacji przekazu, uznanie przekazywanych adresatowi z zewnątrz wartości, norm czy poglądów, musi odznaczać się trzema, uskazanymi przez Herberta C. Kelmana, podstawouymi cechami: władzą, atrakcyjnością i wiarygodnością ${ }^{13}$. Nie bez znaczenia zatem będzie tu występująca w języku badanych przekazów także funkcja ekspresywna.

H4. W warstwie informacyjnej nadawca przekaże podstawowe dane o COVID-19, sposobach rozprzestrzeniania się koronawirusa, trybie postępowania w przypadku zarażenia. Posiłkując się przede uszystkim zdaniami oznajmującymi, neutralnymi emocjonalnie, uskaże odbiorcy korzyści i ewentualne straty wynikłe z reakcji lub z jej braku na komunikaty nadawcy.

H5. Ponieważ w przyjętej narracji w walce z pandemią najważniejsze są zdrowie i bezpieczeństwo każdego człowieka, wzmocnienie funkcji impresywnej werbalnych przekazów ma pomóc u skłonieniu go do zastosowania się do zaleceń, nakazów, próśb - podanych w formie wołacza, zdań wykrzyknikowych, w trybie rozkazującym, pytań retorycznych, bezokoliczników, zurotów kierowanych bezpośrednio do odbiorcy - z wykorzystaniem form adresatywnych w 2. osobie liczby pojedynczej i liczby mnogiej.

H6. Dla ułatwienia memoryzacji tekstu nadawca komunikatów wzmocnił je prostą i czytelną wizualizacją. W tej warstwie dominują barwy ciepłe i rysunki w formie znaków ikonicznych. Interpretowane w obszarze modalności kompozycyjnej współgrają z warstuą słouną komunikatów reklamowych.

Autor badał także poziom zaufania obywateli poszczególnych krajów do ich organów zarządzających zdrowiem publicznym oraz do WHO, ale nie podjął się odpowiedzi na nasuwające się pytanie o to, czy poziom zaufania społecznego do władz przekładał się bezpośrednio na poziom społecznej akceptacji ich persuazyjnego przekazu. Wykazanie słuszności takiej tezy wymagałoby pogłębionych badań etnograficznych w poszczególnych krajach, co ze względu na geograficzny zasięg badania nie jest obecnie możliwe. Zamieszczone $w$ tekście informacje na ten temat mogą jednakże wzbogacić wiedzę czytelnika i posłużyć do dalszych badań.

${ }^{13}$ H.C. Kelman, Compliance, identification, and internalization: Three processes of attitude change, „Journal of Conflict Resolution” 1958, Vol. 2, No. 1, s. 51-60, https://scholar.harvard. edu/files/hckelman/files/Compliance_identification_and_internalization.pdf (dostęp: 11.12.2020); idem, Processes of opinion change, „Public Opinion Quarterly” 1961, Vol. 25, s. 57-78, https:// scholar.harvard.edu/files/hckelman/files/ProcessesofOpinion.pdf (dostęp: 11.12.2020). 
Ocena warstuy wizualnej badanych obiektów, zgodnie z zasadami interpretacji tego typu materiałów zaproponowanymi przez Gillian Rose ${ }^{14}$, poza charakterystyką ich odbiorców, koncentrować się będzie przede wszystkim na ich modalności kompozycyjnej - strukturze wizualnej, składowych, kolorystyce - w poszukiwaniu zarówno ich cech odmiennych, jak i podobieństw.

\section{Światowa Organizacja Zdrowia w walce z pandemią i jej kampania spoleczna}

Za początek pandemii COVID-19 uznano zdiagnozowany 17 listopada 2019 roku u mieście Wuhan, w środkowych Chinach, pieruszy przypadek zarażenia wirusem SARS-CoV-2. Epidemia, przekraczająca błyskawicznie granice państu i kontynenty, 11 marca 2020 roku została uznana przez WHO za pandemię, której centrum 13 marca stała się Europa. Przeciudziałanie pouszechnemu zagrożeniu wymagało działań zarówno w skali globalnej, jak i poszczególnych państu.

WHO, zrzeszająca 194 kraje, to światowy autorytet w kwestiach zdrowotnych. To ona jako organizacja należąca do ONZ stała się wiodącym podmiotem dysponującym wiedzą o tym, czym jest koronawirus i jak się przed nim bronić, jak zapobiegać jego rozprzestrzenianiu, jak zachowywać się po rozpoznaniu zakażenia. Badanie Pew Research Center przeprowadzone latem 2020 roku w czternastu najbardziej rozwiniętych krajach dowodzi, że średnio 63\% badanych respondentów dobrze lub bardzo dobrze ocenia działania podjęte przez WHO w walce z COVID-19. Warto podkreślić, że w odniesieniu do działań podjętych w tym zakresie przez Unię Europejską uskánnik ten uynosi $60 \%{ }^{15}$ Jak pokazują sondaże, WHO dla większości obywateli świata jest podmiotem cieszącym się dużym zaufaniem, co może uskazywać na to, że kompetencje i wiarygodność tej organizacji dają podstawę do założenia, iż jej komunikaty spotykają się z pozytywnym przyjęciem ze strony odbiorców ${ }^{16}$. Przytoczone dane dotyczące autorytetu i wiarygodności nadawcy wśród krajów świata potwierdzają prawdziwość hipotezy H3 w odniesieniu do kampanii przygotowanych przez WHO.

Światowa Organizacja Zdrowia od początku pandemii skupiła się na informacji dotyczącej samej pandemii i zagrożeń, jakie ze sobą niesie, zapoznaniu odbiorców z pełnym zakresem objawów COVID-19 i w przypadku ich wystąpienia - postępowanie zgodnie ze uskazaniami krajouych organów ds. zdrowia (funkcja informatywna języka przekazu). Ponadto zalecała pouszechnie dziś znaną triadę: noszenie maseczek

${ }^{14}$ G. Rose, Interpretacja materiałów wizualnych. Krytyczna metodologia badań nad wizualnościa, przeł. E. Klekot, Wydawnictwo Naukowe PWN, Warszawa 2010.

${ }^{15} \mathrm{M}$. Mordecai, How people around the world see the World Health Organization's initial coronavirus response, ak. 6, https://www.pewresearch.org/fact-tank/2020/11/12/how-people-around-the-world-see-the-world-health-organizations-initial-coronavirus-response/ (dostęp: 6.11.2020).

${ }^{16}$ Raport WEF uskazuje na konieczność wzmocnienia roli WHO w przypadku uystąpienia zagrożeń dla zdrowia publicznego na poziomie światouym, o czym sygnalizowano już w przypadku epidemii eboli i H1N1 - por. Global Risks..., s. 73. 
adekwatnych do stopnia zagrożenia, dystans fizyczny od innych osób oraz częste mycie rąk, a także: wentylację pomieszczeń, kaszel w zgięty łokieć lub chusteczkę, unikanie przestrzeni zamkniętych, zatłoczonych i wymagających bliskiego kontaktu z innymi ${ }^{17}$ (funkcja impresywna języka przekazu). To potwierdza prawdziwość zarówno H1, jak i H2.

Zalecenia te organizacja uspiera ulotkami i plakatami, przygotowanymi w większości w oficjalnych językach ONZ, które można pobierać z zakładek jej strony internetowej. W angielskiej wersji językowej w październiku 2020 roku było ich ponad sto. Znacznej ich części towarzyszyły kilkudziesięciosekundowe spoty w serwisie YouTube. Trzynaście z nich, w polskiej wersji językowej, można pobrać ze strony Państuowego Zakładu Higieny ${ }^{18}$.

Każdy z materiałów poddanych analizie (którą ograniczono do wersji anglojęzycznej oraz nielicznych odpowiedników polskich) odwołuje się, rozszerza, wizualizuje konkretne zalecenie WHO, niektóre $\mathrm{w}$ formule A\&Q (pytanie i odpowiedź) lub w postaci hasel ze sfery racji ${ }^{19}$, wyrażających nakaz, zakaz bądź apel we wzmacniającym sugestyuność tekstu reklamowego trybie rozkazującym - główną formą adresatywną jest 2. osoba liczby pojedynczej. Potwierdzają to plakaty w języku polskim (nie zwracają się one do odbiorców w 2. osobie liczby mnogiej, jak można by ewentualnie sądzić z plakatów w wersji anglojęzycznej) - Bądź gotowy walczyć z COVID-19 (il. 1-2), czyli: bądź poinformowany, bądź przygotowany, bądź mądry, bądź ostrożny, bądź uspierający (wspieraj innych) i troskliwy, zdobywaj informacje o COVID-19, bądź czujny, bądź miły/uprzejmy (dla innych). To potwierdza praudziwość H4 i H5.

Każde z wezwań zostaje rozwinięte, trochę podobnie jak w reklamie teaserowej, w formie osobnych, uszczegóławiających informacji, w osobnym plakacie (il. 1 i 3, 2 i 4).

\footnotetext{
17 Ang. „Avoid the 3Cs: spaces that are closed, crouded or involve close contact” - Unikaj trzech C: przestrzeni zamkniętych, zatłoczonych i wymagających bliskiego kontaktu z innymi. Por. Coronavirus disease (COVID-19) advice for the public, World Health Organization, ak. 5, https://wuw.who.int/emergencies/diseases/novel-coronavirus-2019/advice-for-public/dostęp: 2.11.2020; 9.11.2020).

${ }_{18}$ „Jak uchronić się przed koronawirusem?” Infografiki Światowej Organizacji Zdrowia WHO, https://www.pzh.gov.pl/jak-uchronic-sie-przed-koronawirusem-infografiki-swiatowej-organizacji-zdrowia-who/ (dostęp: 7.11.2020).

19 Szerzej zob. o sferach, do których nadawca odwołuje się w komunikacie reklamowym zob. A. Wójciuk, Perswazja w reklamach społecznych, „Zeszyty Naukowe Towarzystwa Doktorantóu UJ”. Nauki Humanistyczne 2016, nr 2, s. 113-114.
} 

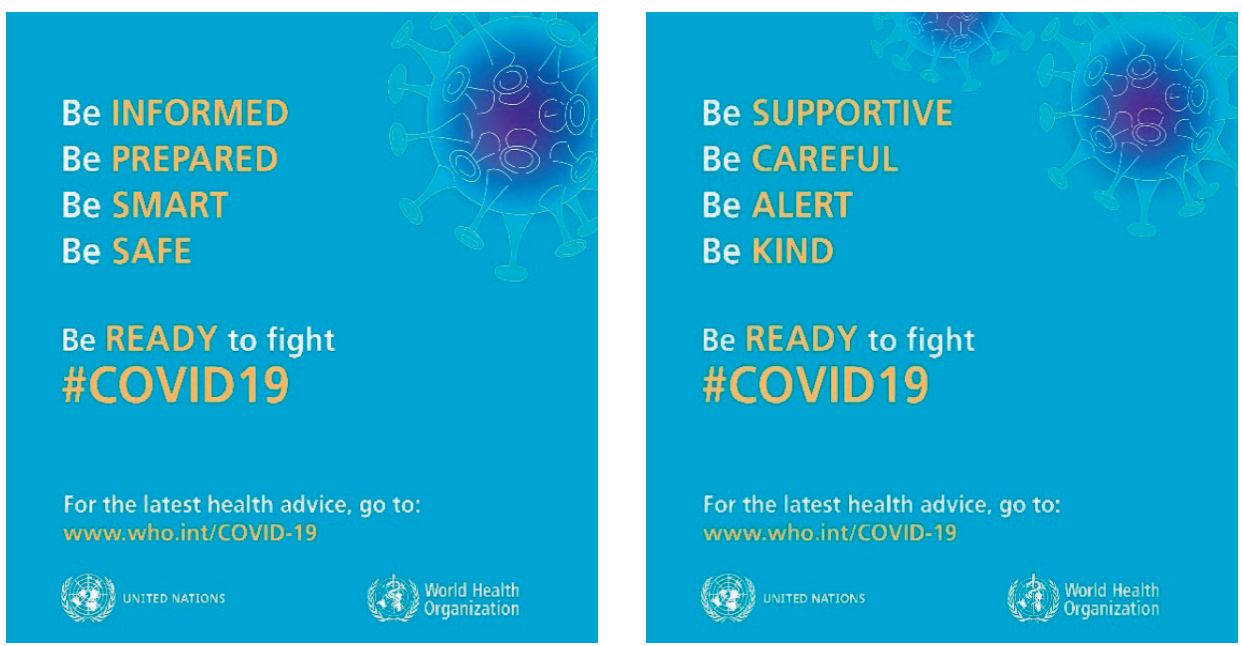

Il. 1-2.
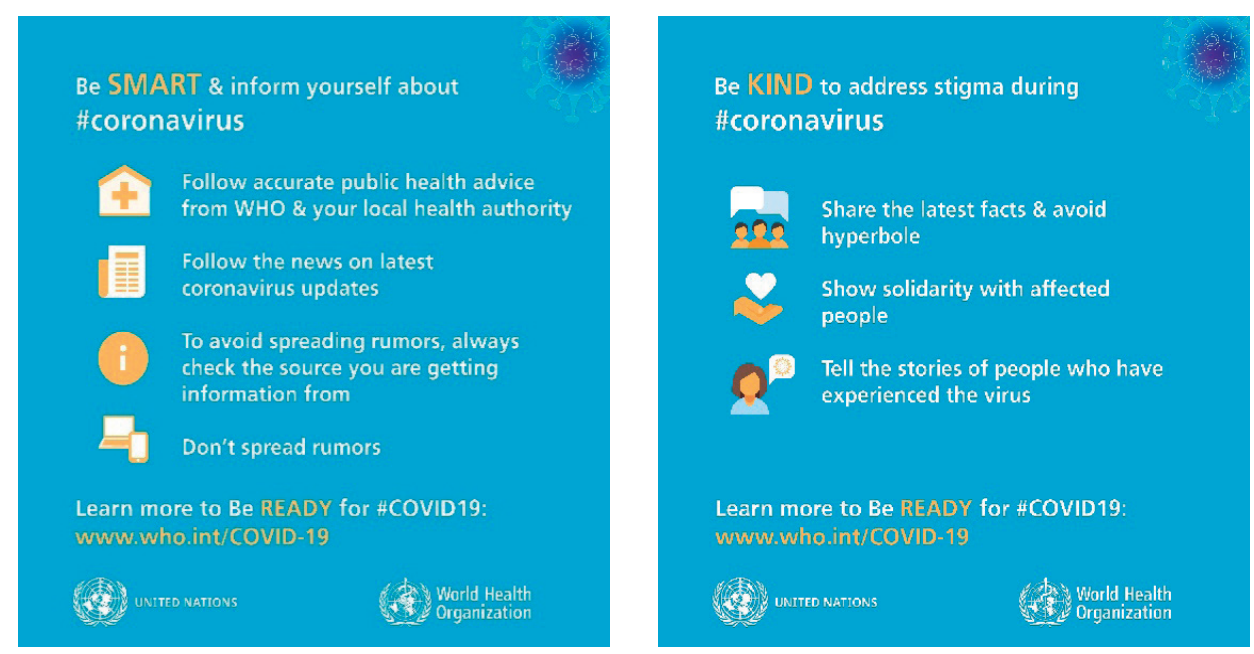

Il. 3-4.

Część materiałów przygotowano u formie uyjaśnień i instruktażu (czyli dlaczego należy coś robić lub jak to robić - w odniesieniu do większości czynności codziennego dnia człowieka), np. jak używać/jak nie używać maseczek (il. 7-8), jak myć ręce (il. 5), jak prać i suszyć ubrana, ręczniki i pościel, jeśli u gospodarstwie domowym jest ktoś podejrzany lub zarażony COVID-19, jak opiekować się podejrzanym/zarażonym w domu, jak myć mięso, owoce i warzywa (il. 11), jak kobieta w ciąży powinna chronić się przed COVID-19 (il. 12), jak radzić sobie ze stresem, jak chronić się w podróży, jak być aktyunym nawet u domu, jak chronić seniorów (il. 13), dlaczego należy być aktywnym (il. 14) itp. Pytania te pełnią w komunikatach rolę nagłówka. 
Krzysztof Stępniak

Osobny rodzaj posterów poświęcono wyjaśnianiu mitów i zualczaniu fake newsów dotyczących pandemii (il. 15). Polskojęzyczne materiały WHO w znacznej części są wierną repliką wersji anglojęzycznych (il. 5 i 6), ale także rozszerzają informacyjną część instruktażową (por. il. 9 i 10).

\section{Wash your hands}

Wash your hands with soap and running water when hands are visibly

dirty

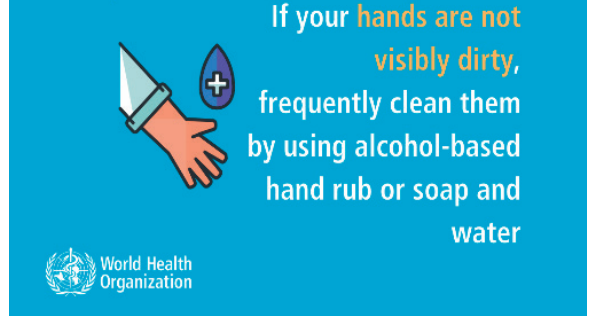

Il. 5. Il. 6.

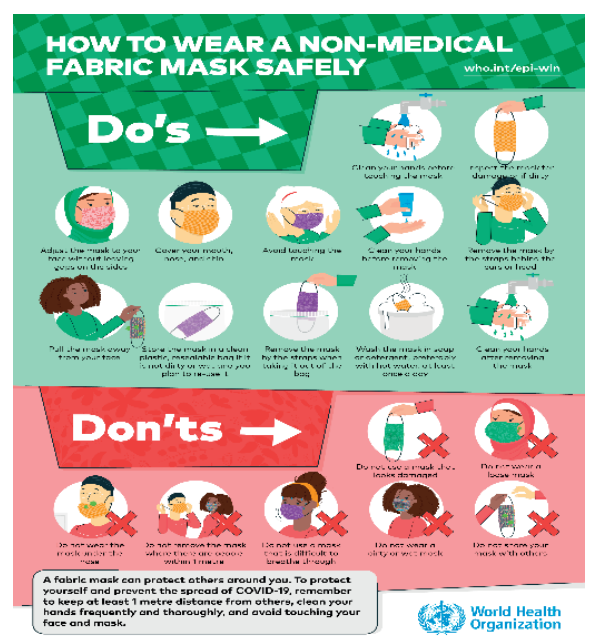

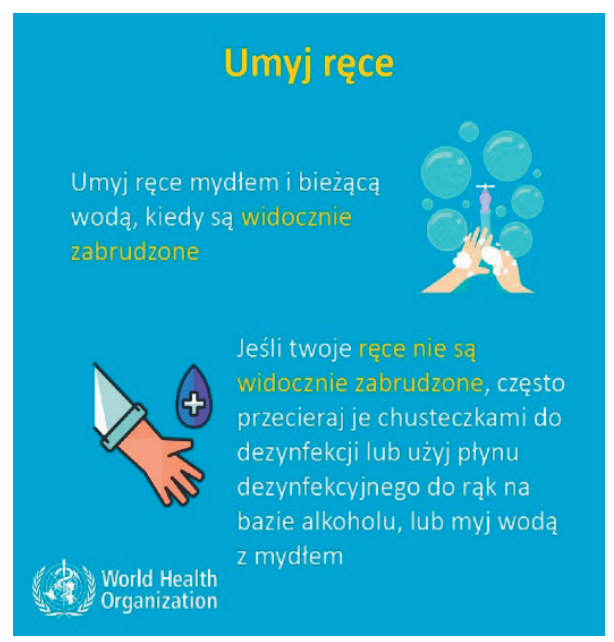

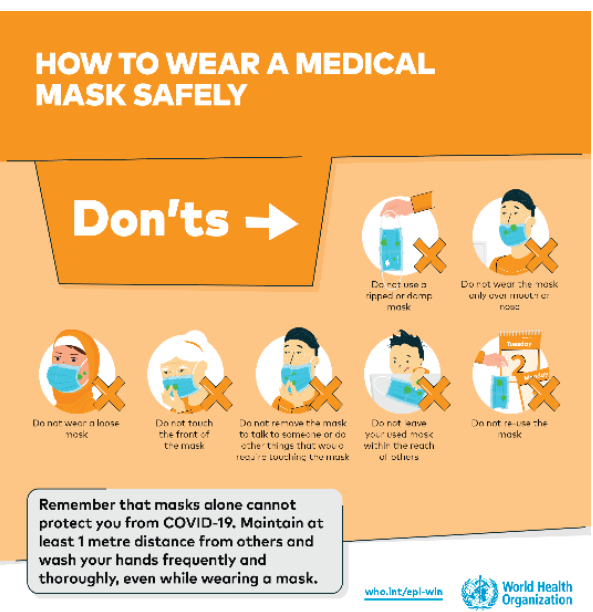

Il. 7. Il. 8. 


\section{Protect others from getting sick}

When coughing and sneezing

cover mouth and nose with

flexed elbow or tissue
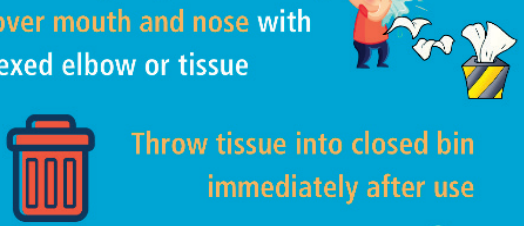

Throw tissue into closed bin

immediately after use

Clean hands with alcohol-based hand rub or soap and water after coughing or sneezing and when caring for the sick

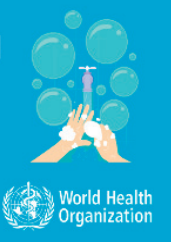

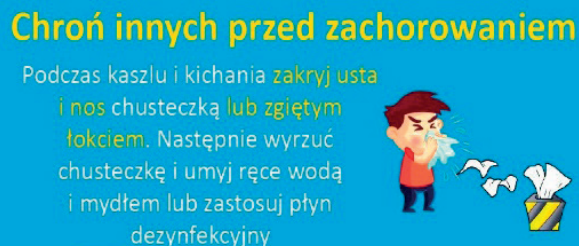
dezynfekcyiny

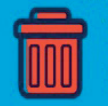

Wyrzuć chusteczkę do zamkniętego kosza bezpośrednio po użyciu

Po kaszlu, kichaniu oraz podczas opieki nad chorym, przecieraj ręce chusteczkami do dezynfekcji lub płynem do dezynfekcji na bazie alkoholu, lub myj ręce wodą i mydłem

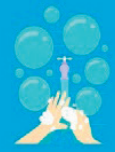

II. 9. II. 10

How should I wash fruit wash them the same way you would in and vegetables in the time of COVID-19?

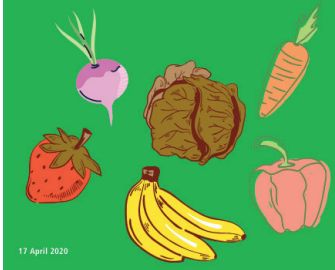

Before handling them, wash your hands with soap and water.

Then, wash fruit and vegetables thoroughly with clean water, especially if you eat them raw.

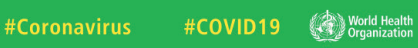

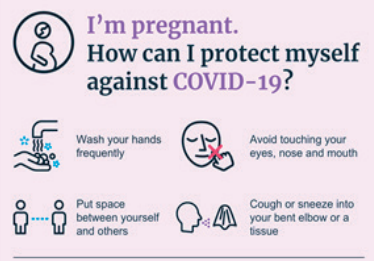

If you have fever, cough or difficulty breathing, seek care early. call beforehand, and follow medical advice.

(k) World Health

II. 11. Il. 12.
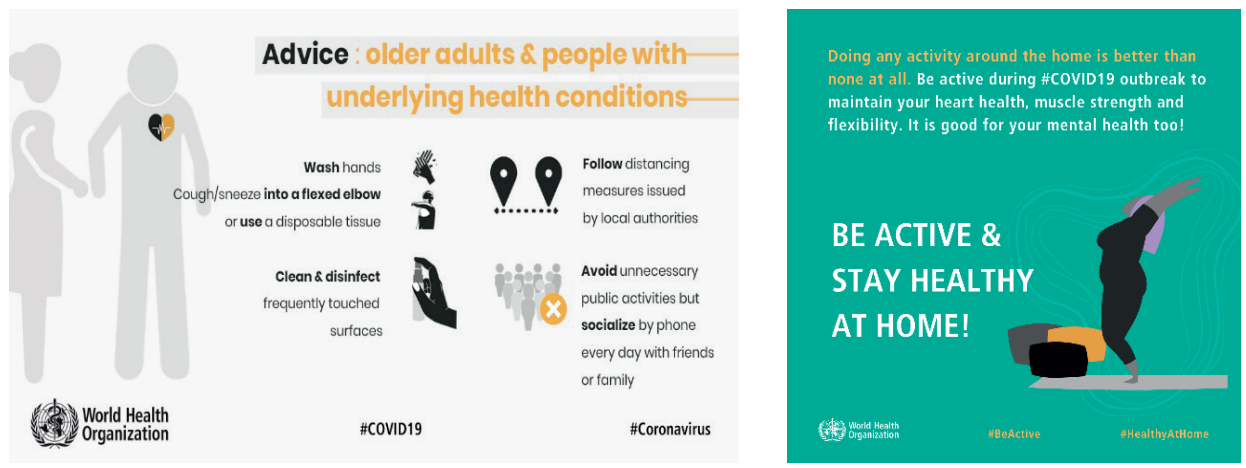

Il. 13. Il. 14. 
The virus that causes COVID-19 is in a

family of viruses called Coronaviridae.

Antibiotics do not work against viruses.

Some people who become ill with COVID-

19 can also develop a bacterial infection as

a complication. In this case, antibiotics may

be recommended by a healthcare provider.

There is currently no licensed medication

to cure COVID-19. If you have symptoms,

call your health care provider or COVID-19

hotline for assistance.

Il. 15.

Rozbudowane teksty językowe o charakterze informacyjno-perswazyjnym i o uniwersalnym przesłaniu edukacyjnym, ważnym zwłaszcza na początku pandemii, mają trafiać z przesłaniem zarówno do wszystkich mieszkańców świata, jak i każdego pojedynczego człowieka (osobne plakaty skierowano do kobiet w ciąży i karmiących oraz osób starszych ${ }^{20}$. Jest ono wzmacniane niewielkimi uproszczonymi rysunkami, przypominającymi łatwo upadające $\mathrm{w}$ oko i z łatwością zapamiętywane znaki ikoniczne, których przekaz po kilku miesiącach pandemii jest jasny dla odbiorców. Postery udostępnione przez WHO światowej publiczności, pogrupowane według tematów, złożyłyby się na obszerną prezentację w PowerPoint.

W warstwie wizualnej interpretacja kampanii reklamowej przygotowanej przez WHO dotyczy jednego z obszarów modalności opisywanych przez Gillian Rose modalności kompozycyjnej. Biorąc pod uwagę interpretację kompozycyjną i relację z tekstem pisanym, należy podkreślić, że w kolorystyce w większości posterów użyto pastelowych barw, choć zauważalnie - zwłaszcza w angielskiej wersji językowej przeważa barwa niebieska, dominująca u identyfikacji wizualnej „rodziny” Organizacji Narodów Zjednoczonych ${ }^{21}$ i WHO jako jej „organu zarządzającego i koordynującego w zakresie zdrowia w skali międzynarodowej"22. Kolor ten w psychologii reklamy jest uznawany za symbol harmonii, spokoju i pozytywnego działania, co w przypadku niosącej grozę pandemii niewątpliwie może działać łagodząco na psychikę odbiorcy. Plakaty odnoszące się do zdrowej diety, codziennych praktyk człowieka związanych

${ }^{20}$ Older people \& COVID-19, https://www.who.int/teams/social-determinants-of-health/ COVID-19 (dostęp: 30.11.2020).

${ }^{21}$ W kolorze niebieskim jest zaróuno flaga, jak i logo ONZ, ale także np. siły pokojoue ONZ zuane są potocznie „niebieskimi hełmami”. Na części antycovidouych plakatóu WHO oprócz jej logo widnieje też logo ONZ.

${ }_{22}$ Our values, our DNA, ak. 1, https://www.who.int/about/who-we-are/our-values (dostęp: 5.11.2020). 
z higieną (np. praniem) czy używaniem monet i banknotów przygotowano w wersji zielonej, a adresowane do kobiet w ciąży i karmiących oraz seniorów - w delikatnych barwach różu, lila, jasnopomarańczowych. Rzadziej stosowano barwę żółtą, a czerwonej użyto dla wzmocnienia zakazu wykonywania jakiejś czynności bądź ostrzeżenia przed jakimś zachowaniem (ang. don'ts..., ros. чего не нужно делать). Przyjęcie określonej baruy tła dla poszczególnych kategorii tematycznych i zastosowanie w odniesieniu do ich elementów werbalnych czcionki (Arial) w kolorze pastelowym (nagłówek) i białym (u jego rozwinięciu) osłabiło wartość informacyjną plakatów WHO - odbiorca na pierwszy rzut oka dostrzega dominujący kolor apli. W przypadku posteróu zawierających więcej tekstu, zułaszcza zapisanego niepogrubioną czcionką (np. il. 10), może mieć problem z odbiorem ich przesłania.

Materiały wizualne przygotowane przez WHO, jak uspomniano, traktujemy w badaniu jako wzorzec, punkt odniesienia do analizy materiałów przygotowanych w poszczególnych krajach.

\section{Kampania społeczna na rzecz walki z koronawirusem w Polsce jako wybrany case study}

Akceptacja, skuteczność przekazów perswazyjnych zależy między innymi od wiarygodności, atrakcyjności i bezstronności ich źródła. Przeważająca większość Polaków w kwestii pandemicznych zagrożeń ufa WHO. Zupełnie inaczej wygląda to jednak w odniesieniu do głównego podmiotu odpowiedzialnego za walkę z COVID-19 w Polsce, jakim jest Ministerstuo Zdrowia. Ono także odpowiada za komunikację ze społeczeństuem w kwestiach pandemii. Dane uzyskane w badaniu ARC Rynek i Opinia uskazują, że resortowi temu na początku pandemii ufało jedynie 51\% polskich obywateli ${ }^{23}$. Z kolei badanie zrealizowane w dniach 1-3 grudnia 2020 roku przez agencję badawczą SW Research na reprezentatyunej próbie Polaków, w ramach badania omnibusouego OmniWatch48, przyniosło wyniki świadczące o niskim poziomie zaufania społecznego do podawanych przez resort danych dotyczących pandemii: „co drugi Polak (52\%) nie wierzy w dzienne raporty Ministerstua Zdrowia, co trzeci (32\%) nie ma wyrobionej opinii, a zaledwie co szósty (16\%) jest przekonany o prawdziwości danych o zakażeniach" 24 . Nie wnikając w przyczyny takiego stosunku Polaków do rządowego organu odpowiedzialnego za zdrowie obywateli, na ustępie już, przedstawiając polskie Ministerstwo Zdrowia jako nadawcę komunikatu perswazyjnego, można stwierdzić, że musi się ono mierzyć nie tylko z samą epidemią, lecz przy niskim poziomie zaufania społecznego także z niebezpieczeństuem uystąpienia - w odpowiedzi na jego antycovidową kampanię - efektu bumerangu, zjawiska psychologicznej reaktancji, która może

\footnotetext{
${ }^{23}$ Koronawirus - najbardziej ufamy lekarzom, https://arc.com.pl/Koronawirus-najbardziej-ufamy-lekarzom-blog-pol-1585326759.html (dostęp: 10.12.2020).

${ }^{24}$ Polacy nie wierza $w$ dane Ministerstwa Zdrowia o zakażeniach COVID-19, https:// shareinfo.pl/polacy-nie-wierza-u-dane-ministerstwa-zdrowia-o-zakazeniach-COVID-19/ (dostęp: 8.12.2020).
} 
skutkować odrzuceniem przez odbiorców treści przekazu, a nawet działaniem ubrew zaleceniom $^{25}$. Nieuielki stopień zaufania społecznego wobec jednostki odpowiedzialnej za komunikację stawia pod znakiem zapytania prawdziwość tezy H3.

Pieruszy przypadek zarażenia koronawirusem w Polsce odnotowano 4 marca $2020 \mathrm{roku}^{26}$, a w pieruszej dekadzie lutego 2021 roku liczba zgonów przekroczyła 40 tysięcy $^{27}$. Ministerstwo Zdrowia już 1 marca 2020 roku zamieściło informację na Facebooku o możliwości pobrania z serwisu Rzeczypospolitej Polskiej gov.pl plakatów zawierających zalecenia dotyczące profilaktyki COVID-19². Zaktualizowany na początku października zbiór ${ }^{29}$ zawierał dwa plakaty przygotowane w językach polskim, angielskim, niemieckim, rosyjskim, ukraińskim, wietnamskim i chińskim: ogólny, informujący o najważniejszych zaleceniach dotyczących postępowania u czasie epidemii (il. 16), oraz drugi (il. 17), z podobnymi informacjami, przeznaczony dla szpitali. Zdecydowanie dominuje $\mathrm{w}$ nim funkcja informatywna języka w warstuie werbalnej, co potwierdza tezę H1.

Osobne plakaty przygotowano dla seniorów, osób przybywających z zagranicy oraz informujące o trybie postępowania po poddaniu się testowi na COVID-19. W odróżnieniu od plakatów WHO wśród odbiorców nie wyodrębniono kobiet u ciąży. Plakaty WHO, adresowane do wszystkich ludzi, w każdym kraju, po dalsze informacje odsyłały do właściuyych organów państu - w przypadku Polski wszystkie główne plakaty mające logo Ministerstwa Zdrowia, Narodowego Funduszu Zdrowia i Państwowej Inspekcji Sanitarnej, podają numer infolinii NFZ oraz adres informacyjnej rządowej strony internetowej. Osobny plakat zachęca do pobrania aplikacji ProteGO Safe $^{30}$ (il. 24).

Podobnie jak w plakatach WHO, w materiałach polskich dominuje tekst językowy, wsparty w głównych plakatach niewielkimi znakami ikonicznymi. Zalecenia, zgodne z tymi przygotowanymi przez WHO, są przekazywane w trybie rozkazującym,

${ }_{25}$ Szerzej zob. E. Bielska, Koncepcje oporu we wspótczesnych naukach społecznych. Główne problemy, pojęcia, rozstrzygnięcia, Wydaunictwo Uniwersytetu Śląskiego, Katowice 2013, s. 160 i n.; W.J. Paluchouski, Komunikacja perswazyjna a reklama, „Ruch Prawniczy, Ekonomiczny i Socjologiczny" 1994, z. 2, s. 116.

${ }^{26}$ Pierwszy przypadek koronawirusa w Polsce, https://www.gov.pl/web/zdrowie/pierwszy-przypadek-koronawirusa-w-polsce (dostęp: 8.11.2020).

${ }^{27}$ Raport zakażeń koronawirusem (SARS-CoV-2) https://www.gov.pl/web/koronawirus/ wykaz-zarazen-koronawirusem-sars-cov-2 (dostęp: 11.02.2021) (dane Ministerstua Zdrowia RP z 11 lutego 2021 r.).

${ }^{28}$ https://www.facebook.com/135889759813803/photos/-szukasz-materia\%C5\%82\%C3\%B3w-o-koronawirus-\%EF\%B8\%8Fplakaty-do-pobraniauydruku-a-tak\%C5\%BCe-aktualne-k/ 2711195408949879/ (dostęp: 8.11.2020).

${ }^{29}$ Koronawirus: informacje i zalecenia, https://www.gov.pl/web/koronawirus/do-pobrania (dostęp: 8.11.2020).

30 Aplikacja umożliwia samokontrolę własnego stanu zdrowia i prowadzenie Dziennika Zdrowia, zawiera Test Oceny Ryzyka oraz komunikaty potwierdzone przez Ministerstwo Zdrowia lub Główny Inspektorat Sanitarny, opracowane na podstawie danych Europejskiego Centrum ds. Zapobiegania i Kontroli Chorób (ECDC) oraz WHO. Por. ProteGO Safe, https://uwu.gov.pl/ web/koronawirus/protegosafe (dostęp: 13.12.2020). 
z reguły jako odpowiedź na pytanie pełniące rolę nagłówka sloganu (co robić lub czego nie robić):

- Myj często ręce wodą z mydłem lub dezynfekuj je środkiem odkażającym na bazie alkoholu (co najmniej 60\%).

- Unikaj dotykania rękami oczu, nosa i ust.

- Unikaj kontaktu z osobami chorymi.

- Kiedy kaszlesz lub kichasz, zakrywaj usta i nos zgiętym ramieniem lub jednorazową chusteczką. Zachowaj co najmniej 1,5 metra odległości od innych osób.

- Zasłaniaj usta i nos w ogólnodostępnych przestrzeniach zamkniętych oraz w środkach komunikacji.

- W przypadku uystąpienia objawów charakterystycznych dla COVID-19 skontaktuj się telefonicznie z lekarzem podstawowej opieki zdrowotnej lub w przypadkach zagrożenia zdrowia lub życia, niezułocznie zadzwoń pod numer alarmowy 112 lub 999.

- Przestrzegaj ograniczeń wynikających z przepisów o stanie epidemii.

Ten sposób prowadzenia przekazu informacji potwierdza prawdziwość tez H4 i H5 oraz wzmocnienie funkcji impresywnej języka. W warstwie werbalnej polskie komunikaty dotyczące COVID-19 wskazują na zastosowanie języka perswazji, co potwierdza prawdziwość hipotez H2 i H5.

Główną formą adresatywną jest 2. osoba liczby pojedynczej - nawet w odniesieniu do seniorów i cudzoziemców (il. 19 i 20). Użycie modalnego predykatyuu powinieneś (il. 17) podkreśla nakazowe intencje nadawcy. W przekazie polskiego nadawcy dominuje funkcja informatyuna. Kategoryczna nakazowość osłabia ekspresywną funkcję komunikatu, a w całym akcie komunikacyjnym stroną aktywną jest nadawca, a nie odbiorca.

W warstwie kompozycyjnej, w porównaniu z plakatami WHO - layout polskich materiałów jest skromny, wręcz minimalistyczny, z dominującym nagłówkiem. Większość posterów ma rozbudowaną - w formie instruktażu - informacyjną część przekazu, podającą dokładne informacje. Kampania polska mocno podkreśla źródła dodatkowych informacji, które odbiorca może znaleźć, czemu służy swoiste uwypuklenie graficzne i jego kolorystyka (nr infolinii, adresy www). Polskie materiały są utrzymane w chłodnej (rzecz można eleganckiej), duubarwnej kolorystyce. Zgodnie z systemem identyfikacji wizualnej Ministerstwa Zdrowia i NFZ na plakatach dominuje kolor niebieski w różnych odcieniach. Aby podkreślić niektóre elementy (werbalne i wizualne), wzmocnić ich siłę informacyjną i perswazyjną, użyto koloru czerwonego, najsilniej oddziałującego na odbiorcę, będącego międzynarodową oznaką szpitali i ambulansów, Czerwonego Krzyża, ale kojarzonego też z ogniem, niebezpieczeństuem, krwią. Czytelność przekazu werbalnego wzmacnia biel tła, choć w niektórych plakatach użyta bezszeryfowa czcionka w kolorze szarym czytelność tę osłabia. Ogólnie można stuierdzić, że warstuy kompozycyjna i werbalna wzajemnie się uzupełniają. Warstua językowa jest wzmocniona prostą i czytelną warstwą kompozycyjną, co potwierdza tezę H6. 


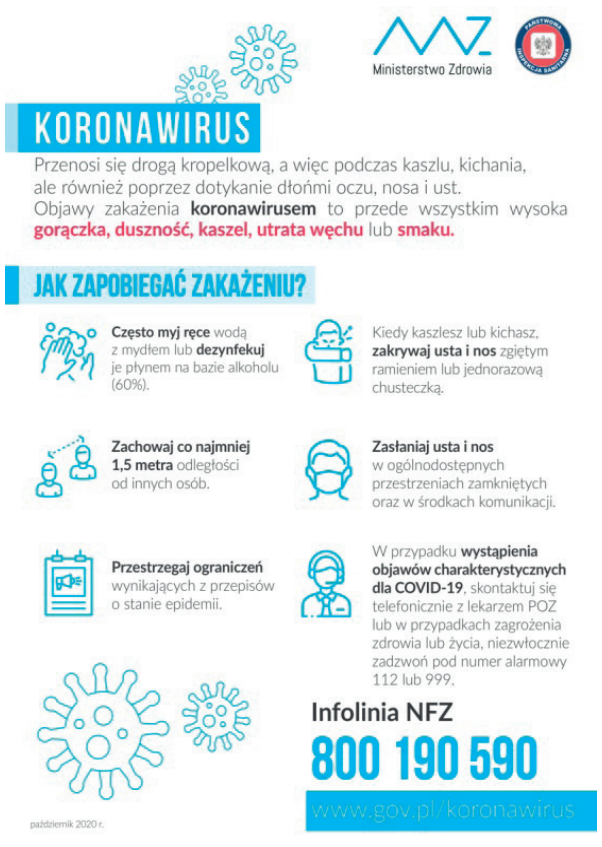

\section{CO POWINIENEŚ WIEDZIEĆ $\cong$ (0) O KWARANTANNIE?}

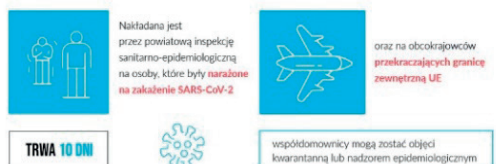

Zainstaluj aplikację Kwarantanna domowa www.gov.pl/kwarantannadomowa
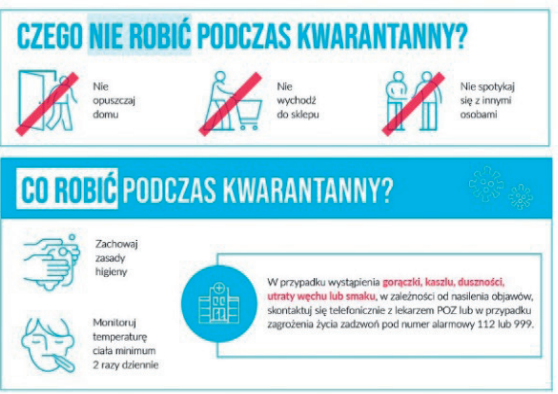

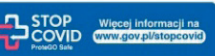

Infolinia NFZ

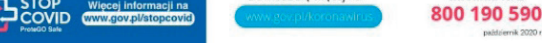

Il. 16. Il. 17.
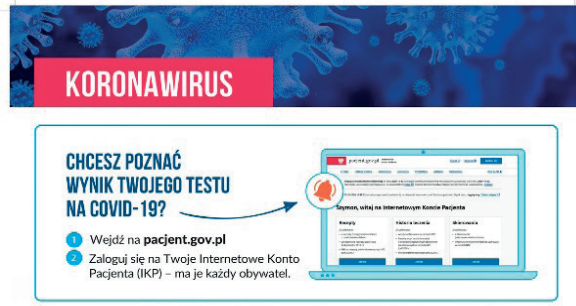

\section{ZNAJOZIESZ TAM}

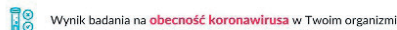

194 Informacie, czy masz obowiazek przebwwac na kwarantannie

NA IKP SA TAKŻE

Twoje e-recepy, e-skierowania oraz inne przydatne informocie dotycace
Twojego zdrowia

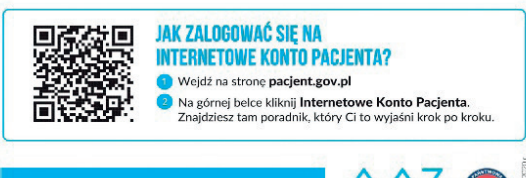

Dowiedz się wieccej na pajeent gov.pl//koronawirus

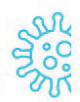

S:0

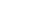

(7)

Il. 18. Il. 19.

\section{SENIORZE!}

\section{Zadbaj o siebie.}

Koronawirus jest szczególnie niebezpieczny a dla seniorów i osób z chorobami towarzyszącymi.

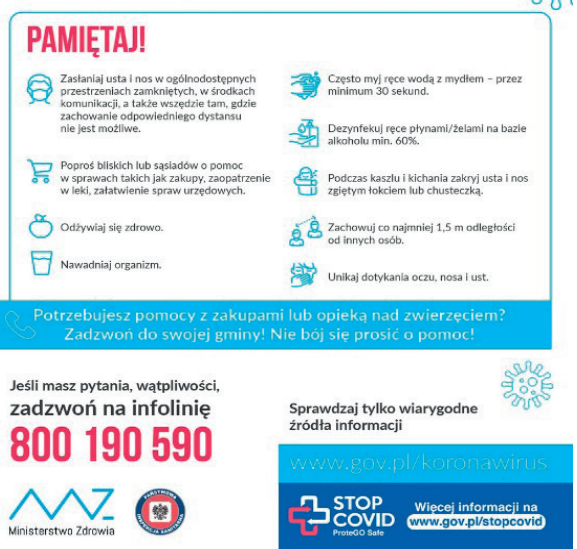




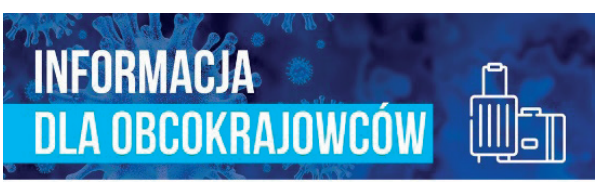

Planujesz podróż do Polski? Przekraczając granicę RP, stanowiącą granicę zewnętrzną UE, musisz odbyć obowiązkową kwarantannę. KWARANTANNA TRWA 10 DNI.

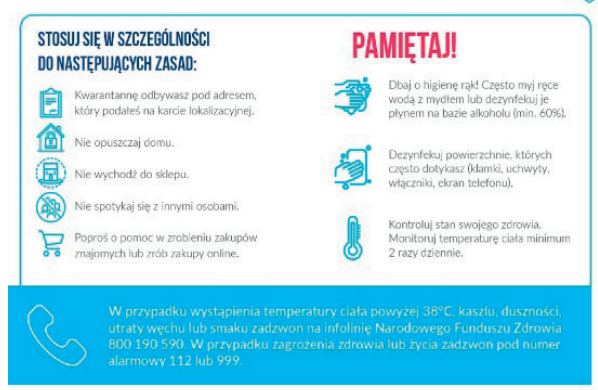

Więcej informacji znajdziesz na Www.gov.pl/koronawirus oraz www.strazgraniczna.pl/pl/cudzoziemcy
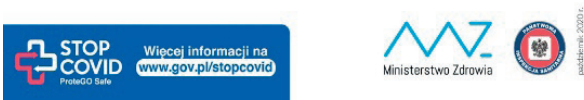

Il. 20 Il. 21

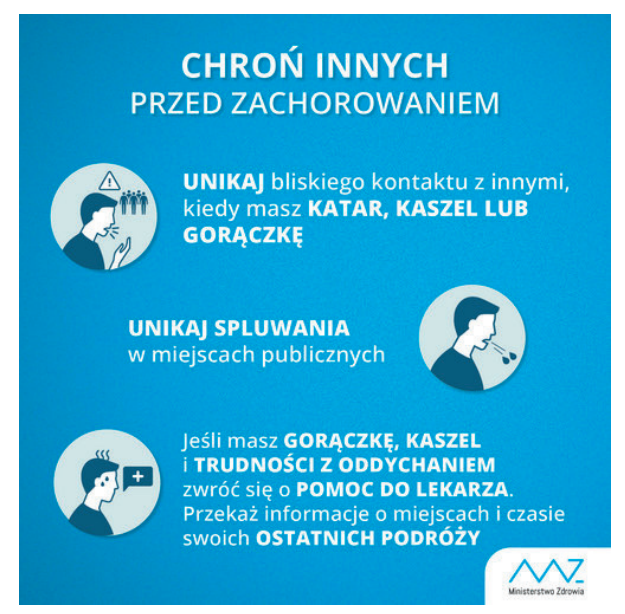

Il. 22. Il. 23.

\section{CHROŃ INNYCH}

kiedy masz KATAR, KASZEL LUB GORĄCZKE

UNIKAJ SPLUWANIA w miejscach publicznych

Jeśli masZ GORACZKE, KASZEL

I TRUDNOŚCI Z ODDYCHANIEM

sWoich OSTATNICH PODRÓżY

W

\section{Jak prawidłowo nałożyć i zdjąć maseczkę \\ World Health ye Organization}

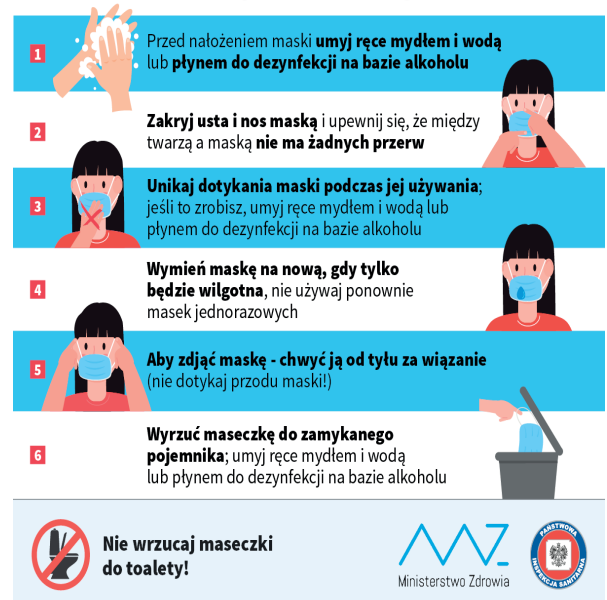

\section{}

\section{Podczas kwarantanny}

NIE opuszczaj domu
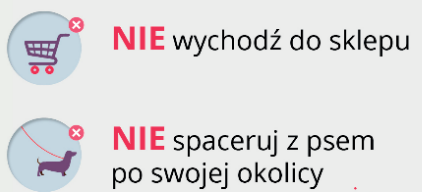

NIE spaceruj z psem po swojej okolicy

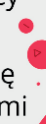




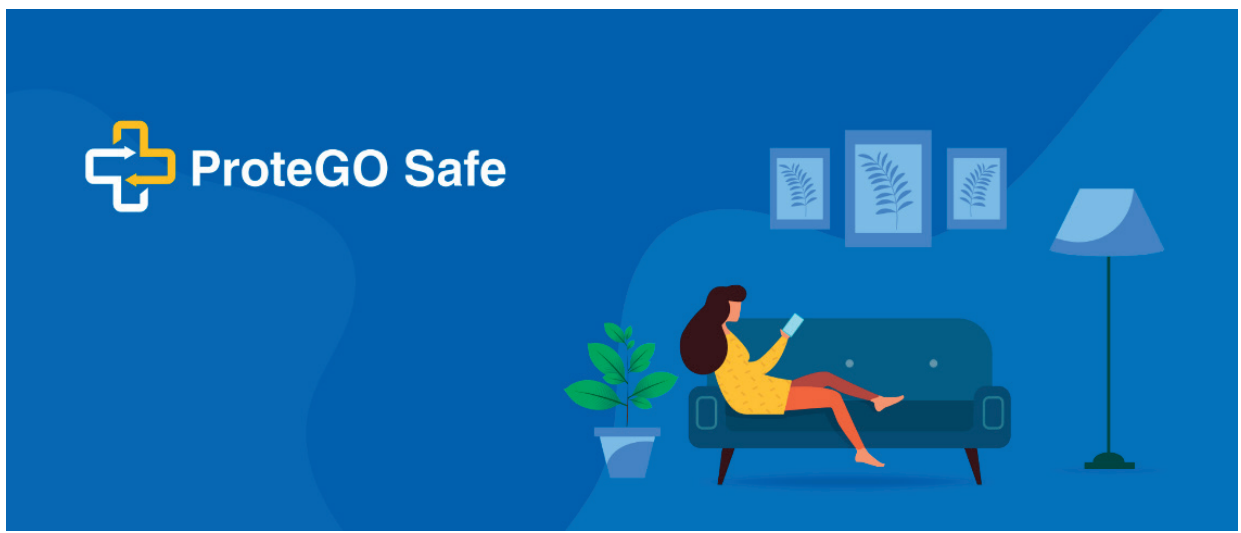

II. 24 .

\section{Podsumowanie}

Świat, stając u obliczu totalnej pandemii spowodowanej przez wirus SARS-CoV-2, musiał podjąć pilne działania informacyjne i profilaktyczne. Jak pokazuje badanie, rządy różnych krajów, na całym świecie, podobnie jak WHO, wykorzystały uszelkie możliwości komunikacyjne, u tym także reklamoue kampanie społeczne, do podjęcia pilnych działań. Warto wspomnieć, że poszczególne plakaty kampanii ogólnoświatowej, jak również poszczególnych państu wybranych w próbie losowej, pojawiały się w mediach społecznościouych na zasadzie wiralu.

Zalecenia WHO zostały przyjęte z pełnym zaufaniem przez większość rządów i społeczeństu. Przeprowadzona analiza komunikatów kierowanych przez WHO oraz rządy wybranych do badania krajów do ich obywateli wykazała, że postawiono w nich przede wszystkim na informację i perswazję, niuansując ich wzajemne relacje. Przekazy polskie w warstwie werbalnej zawierają mocny przekaz informacyjny i perswazyjny. W kampaniach prowadzonych przez rząd naszego kraju postawiono na przekaz werbalny, rezygnując z rozbudowanej warstuy kompozycyjnej - nieco inaczej niż na przykład w Nowej Zelandii czy Australii, co pokażemy u oddzielnej publikacji.

W podjętym badaniu nie postawiono hipotezy dotyczącej zależności między poziomem zaufania społecznego do organów władzy a reakcją społeczną na kampanię społeczną dotyczącą pandemii. Uznanie za słuszną takiej tezy (przy wykazanych w badaniu drastycznych różnicach między poziomem zaufania do władz między poszczególnymi państwami) byłoby rzeczą tyleż kuszącą, co z pewnością błędną bez uwzględnienia wielu zmiennych zależnych od uwarunkowań kulturowych, odnoszących się do backgroundu historycznego, kultury politycznej, struktury społecznej, zdrowotności populacji badanych krajów, trafności kulturowego odkodowania przekazów itp. Jej udowodnienie pozostaje zatem, przynajmniej tu i teraz, kwestią otwartą. 
Na tym etapie badań można jednak stwierdzić, że - niezależnie od stopnia perswazyjności komunikatów - przekazały one społeczeństwom poszczególnych krajów, podobnie jak opisanej Polski, informację o podstawowych zaleceniach WHO w sposób szybki i zrozumiały. Badanie zdaje się potwierdzać główną hipotezę zaczerpniętą od Krastewa, że pandemia wywołana przez SARS-CoV-2 pokazała (przynajmniej w tym zakresie), że żyjemy u „Jednym Śuiecie”.

Paradoksalnie więc pandemia może otworzyć róunież przed badaczami reklamy wiele nowych obszarów eksploracyjnych, w tym międzynarodouych studiów porównawczych, „zdolnych dostarczyć cennych przykładów udanych akcji społecznych z zagranicy, a zarazem stanowiących wartościowe i bogate źródło informacji na temat problemów społecznych istniejących w innych krajach, a także wiedzy na temat ich kultur, społeczeństw i mediów"31.

Podjęte przez autora badanie pokazuje, jak ważnym elementem komunikacji mogą być kampanie społeczne. Reklama społeczna stała się narzędziem coraz częściej stosowanym w celu osiągnięcia pożądanych zmian postaw wobec palących problemów społecznych - poprzez właściwe informowanie, nakłanianie, perswazję. Jest ona często też nazywana reklamą u służbie publicznej (ang. public service advertising) ${ }^{32}$ czy reklamą użyteczności publicznej ${ }^{33}$.

Celem takich kampanii jest wywołanie zmian społecznych, wyrwanie obywateli ze stanu marazmu, przewartościowanie świadomości, uwrażliwienie, wywołanie społecznej dyskusji, swego rodzaju „zysk ideowy”34. Jej towarem do sprzedania są wartości. Ale wzbudza też sympatię, zaufanie, uspółczucie, porusza uczucia, odwołuje się, jak w przypadku analizowanych kampanii do odpowiedzialności za siebie i innych, za siebie i świat.

\section{Bibliografia}

Audet J., d'Amboise G., The Multi-Site Study: An Innovative Research Methodology, „The Qualitative Report" 2012, Vol. 6, No. 2, s. 1-18.

Banks M., Materiały wizualne w badaniach jakościowych, przeł. P. Tomanek, Wydawnictuo Naukoue PWN, Warszawa 2013.

Bielska E., Koncepcje oporu we wspótczesnych naukach społecznych. Główne problemy, pojęcia, rozstrzygnięcia, Wydawnictwo Uniwersytetu Śląskiego, Katowice 2013.

\footnotetext{
${ }^{31}$ M. Krzyszkouski, Ikonologia reklamy społecznej $w$ Polsce $i w$ Szwecji, „Acta Universitatis Lodziensis, Folia Sociologica" 2007, nr 32, s. 73.

${ }_{32}$ B. Goodwill, Public Service Advertising - Background and Future, http://www1.psaresearch. com/bib9830.html (dostęp: 22.10.2020).

${ }_{33}$ Papieska Rada Do Spraw Środków Społecznego Przekazu 1997 [w:] Kościół o mediach. Wybór dokumentów Kościoła o środkach społecznego przekazu, Warszawa 2013, s. 81.

34 A. Wójciuk, Reklama komercyjna i reklama społeczna - różnice i podobieństwa, „Zeszyty Naukowe Towarzystwa Doktorantów UJ". Nauki Społeczne 2017, nr 16, s. 36-40; zob. też A. Stolarska, Wptyw reklamy społecznej na postawy i zachowania odbiorców przekazu, „Roczniki Ekonomii i Zarządzania” 2012, t. 4, s. 309-325.
} 
Casero-Ripollés A., Impact of COVID-19 on the media system. Communicative and democratic consequences of news consumption during the outbreak, „El Profesional de la Información” 2020, Vol. 29, No. 2, s. 1-11 (dostęp: 8.02.2021).

Coronavirus disease (COVID-19) advice for the public, World Health Organization, https:// wuw.who.int/emergencies/diseases/novel-coronavirus-2019/advice-for-public (dostęp: 9.11.2020).

Dańda A., Lubecka J., Casebook. Metodologia tworzenia case study, Wyższa Szkoła Europejska im. ks. Józefa Tischnera, Kraków 2010.

Flyvbjerg B., Pięć mitów o badaniach typu studium przypadku, „Studia Socjologiczne” 2005, nr 2, s. 41-69.

Global Risks Report 2021, 16th Ed., World Economic Forum, Cologny-Geneva 2021.

Goodwill B., Public Service Advertising - Background and Future, http://www1.psaresearch. com/bib9830.html (dostęp: 22.10.2020).

Gustafsson J., Single case studies vs. multiple case studies: A comparative study, 2017-01-12, https://wuw.diva-portal.org/smash/get/diva2:1064378/FULLTEXT01.pdf (dostęp: 30.12.2020).

https://www.facebook.com/135889759813803/photos/-szukasz-materia\%C5\%82\%C3\%B3w-o-koronawirus-\%EF\%B8\%8Fplakaty-do-pobraniawydruku-a-tak\%C5\%BCe-aktualne-k/2711195408949879/ (dostęp: 8.11.2020).

„Jak uchronić się przed koronawirusem?” Infografiki Światowej Organizacji Zdrowia WHO, https://www.pzh.gov.pl/jak-uchronic-sie-przed-koronawirusem-infografiki-swiatowej-organizacji-zdrowia-who/ (dostęp: 7.11.2020).

Jakobson R., Poetyka w świetle językoznawstwa, „Pamiętnik Literacki” 1960, nr 2, s. 431-473.

Kelman H.C., Compliance, identification, and internalization: Three processes of attitude change, „Journal of Conflict Resolution” 1958, Vol. 2, No. 1, s. 51-60, https://scholar. harvard.edu/files/hckelman/files/Compliance_identification_and_internalization.pdf (dostęp: 11.12.2020).

Kelman H.C., Processes of opinion change, „Public Opinion Quarterly” 1961, Vol. 25, s. 57-78, https://scholar.harvard.edu/files/hckelman/files/ProcessesofOpinion.pdf (dostęp: 11.12.2020).

Koronawirus: informacje $i$ zalecenia, https://www.gov.pl/web/koronawirus/do-pobrania (dostęp: 8.11.2020).

Koronawirus - najbardziej ufamy lekarzom, https://arc.com.pl/Koronawirus-najbardziej-ufamy-lekarzom-blog-pol-1585326759.html (dostęp: 10.12.2020).

Krastew I., Nadeszło jutro. Jak pandemia zmienia Europę, przeł. M. Sutouski, Wydaunictuo Krytyki Politycznej, Warszawa 2020.

Krzyszkouski M., Ikonologia reklamy społecznej w Polsce i $w$ Szwecji, „Acta Universitatis Lodziensis. Folia Sociologica" 2007, 32, s. 57-74.

Lalewicz J., Krytyka teorii funkcji mowy Bühlera-Jakobsona, „Teksty” 1973, nr 6, s. 16-33.

Mielcarek P., Metoda case study w rozwoju teorii naukowych, „Organizacja i Kierowanie” 2014, nr 1, s. 105-117.

Mordecai M., How people around the world see the World Health Organization's initial coronavirus response, https:/www.pewresearch.org/fact-tank/2020/11/12/how-people-around-the-world-see-the-world-health-organizations-initial-coronavirus-response/ (dostęp: 6.11.2020).

Nielsen R.K. et al., Navigating the 'Infodemic': How People in Six Countries Access and Rate News and Information about Coronavirus, Oxford 2020, https://reutersinstitute.politics. 
ox.ac.uk/sites/default/files/2020-04/Navigating\%20the\%20Coronavirus\%20Infodemic\%20 FINAL.pdf (dostęp: 8.02.2021).

Older people \& COVID-19, https://www.who.int/teams/social-determinants-of-health/COVID-19 (dostęp: 30.11.2020).

Our values, our DNA, https://www.who.int/about/who-we-are/our-values (dostęp: 5.11.2020).

Paluchouski W.J., Komunikacja perswazyjna a reklama, „Ruch Prawniczy, Ekonomiczny i Socjologiczny" 1994, z. 2, s. 113-124.

Pierwszy przypadek koronawirusa w Polsce, https://www.gov.pl/web/zdrowie/pierwszy-przypadek-koronawirusa-w-polsce (dostęp: 8.11.2020).

Polacy nie wierza $w$ dane Ministerstwa Zdrowia o zakażeniach COVID-19, https://shareinfo. pl/polacy-nie-wierza-w-dane-ministerstwa-zdrowia-o-zakazeniach-COVID-19/ (dostęp: 8.12.2020).

ProteGO Safe, https://wuw.gov.pl/web/koronawirus/protegosafe (dostęp: 13.12.2020).

Raport zakażeń koronawirusem (SARS-CoV-2) https://www.gov.pl/web/koronawirus/wykaz-zarazen-koronawirusem-sars-cov-2 (dostęp: 11.02.2021).

Rose G., Interpretacja materiałów wizualnych. Krytyczna metodologia badań nad wizualnościa, przeł. E. Klekot, Wydawnictwo Naukowe PWN, Warszawa 2010.

Ryłko-Kurpieuska A., Kontrowersje wokół tradycji badań nad komunikatem reklamowym, „Studia Medioznaucze” 2007, nr 4, s. 51-73.

Stolarska A., Wpływ reklamy społecznej na postawy i zachowania odbiorców przekazu, „Roczniki Ekonomii i Zarządzania” 2012, t. 4, s. 309-325.

Wójciuk A., Perswazja w reklamach społecznych, „Zeszyty Naukowe Towarzystua Doktorantów UJ. Nauki Humanistyczne" 2016, nr 2, s. 109-125.

Wójciuk A., Reklama komercyjna i reklama społeczna - różnice i podobieństwa, „Zeszyty Naukowe Touarzystwa Doktorantów UJ. Nauki Społeczne" 2017, nr 16, s. 27-43.

Žižek S., Pandemia! COVID-19 trzęsie światem, przeł. J. Maksymowicz-Hamann, Wydawnictuo Relacja, Warszawa 2020. 